\title{
OPTIMISED ROUTINES FOR MONITORING OF TREATED LATE LATENT SYPHILIS PATIENTS
}

\author{
Dzintars Ozoliṇš*, Ilona Hartmane**, Ingmārs Mikažāns*, Daina Paegle**, \\ Ināra Ančupāne ${ }^{\star \star \star}$, and Aija Žileviča ${ }^{\star \star \star \star}$ \\ * Centre of Sexually Transmitted and Skin Diseases, Pauls Stradiṇš Clinical Hospital, Pērnavas iela 70, Rīga, LV-1009, LATVIA \\ ** Clinical Centre of Skin and Sexually Transmitted Diseases, A. Briāna iela 2, Rīga, LV-1001, LATVIA \\ ${ }^{* * *}$ Children's Hospital of Rīga Stradinš̌ University, Vienības gatve 45, Rīga, LV-1004, LATVIA \\ ${ }^{* \star * *}$ Faculty of Medicine, University of Latvia, Šarlotes iela 1a, Rĩga, LV-1001, LATVIA
}

Contributed by Aija Žileviča

\begin{abstract}
Highly sensitive and specific tests are needed in monitoring of the serological activity and efficacy of treatment of late latent syphilis. In a retrospective study, the data of 52 patients who had received treatment for late latent syphilis were analysed in the Clinical Centre of Skin and Sexually Transmitted Diseases, Latvia. The diagnostic sensitivity and specificity was calculated by Syphilis Immunoblot IgG, Treponema Pallidum Immobilisation Reaction (TPIR) and Syphilis Express Diagnosis (SED). The correlation between Treponema Pallidum Immobilisation Reaction (TPIR) and Syphilis Immunoblot IgG, SED and TPIR results were estimated. Syphilis Immunoblot IgG is useful for latent syphilis diagnostics. The values of the synthetic peptide TmpA, TmpN15 and TmpN47 on the Syphilis Immunoblot IgG strip are useful for monitoring of the treatment of late latent syphilis patients.
\end{abstract}

Key words: syphilis, serological diagnostics, treatment monitoring.

\section{INTRODUCTION}

Syphilis is a disease caused by bacterium Treponema pallidum subspecies pallidum. The term "serological activity" is considered in describing syphilis, to indicate the level of antibodies against $T$. pallidum subsp. pallidum in human blood. False positive serologic reactions are not rare because of cross-reactions with a concomitant disease or technical mistake (Haake, 2000; Bouis et al., 2001; Porcella and Schwan, 2001).

Since 1990, there has been a growing trend in the incidence of both acquired and congenital syphilis in European countries, especially in Eastern Europe. The incidence of syphilis has increased worldwide, and is clearly associated with urban agglomerates and sexual tourism destinations (Woznicova and Valisova, 2007). The syphilis incidence in Latvia has been steadily decreasing in the past few years, but remains still high in comparison with more developed countries (Ozoliňš et al., 2006). As a syphilitic infection can produce a variable range of symptoms in humans, laboratory tests are often required to definitively diagnose an infection (Brinkman et al., 2006).

Infection is initiated when T. pallidum subsp. pallidum penetrates dermal microabrasions or intact mucous membranes, typically resulting in a single chancre at the site of inoculation. The primary chancre develops about three weeks after exposure; the incubation period ranges between 10 and 90 days. The primary chancre heals spontaneously within four to six weeks, but may still be discernible in about $15 \%$ of patients at the onset of secondary syphilis (Rompalo et al., 2001). Within hours of inoculation, and during evaluation of the primary stage, $T$. pallidum subsp. pallidum disseminates widely in a variety of tissues. Manifestations of secondary syphilis usually occur within three months of initial infection. The most common manifestation of secondary syphilis is a disseminated mucocutaneous rash. Disseminated lesions of secondary syphilis usually resolve spontaneously within three months of appearance, and symptoms are absent for a variable period of time in untreated individuals. Latent syphilis is divided into two stages, based on an approximation of the time of infection. In the first year after infection, patients are considered to have early latent syphilis; up to $25 \%$ may have recurrent secondary manifestations (Gjestland, 1955). Late latent syphilis is defined as an asymptomatic infection of longer than one year or unknown duration. Serologic testing during the late latent stage is positive, but sexual transmission is unlikely. T. pallidum may seed the bloodstream intermittently during latent syphilis and can infect the developing foetus during pregnancy. A schematic diagram of untreated syphilis is shown in Fig. 1. 


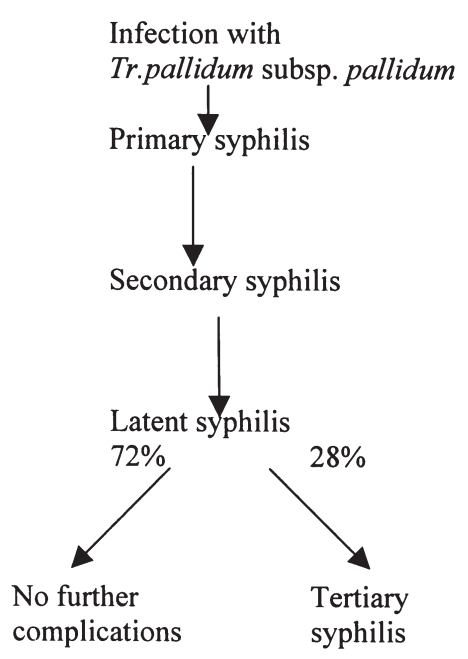

Growth of bacteria at site of infection,

dissemination to various tissues

including central nervous system

Chancre at the site of infection,

regional lymphadenopathy

Disseminated rash, generalised

lymphadenopathy

Recurrence of secondary syphilis

symptoms up to $25 \%$ of individuals

Gumma, cardiovascular syphilis, late neurological complications
Fig. 1. Natural history of untreated syphilis (Gjestland, 1955).
The determination of the stage of disease is important, because the sensitivity and specificity values of the applied diagnostics methods vary among the different stages of the disease. The prognosis of treatment depends on the stage, and should be considered in monitoring of treatment (Larson, 1995; Goh and Voorst Vader, 2001).

The T. pallidum subsp. pallidum genome, known to be small (Walker et al., 1991; 1995), was confirmed by the Genome Sequencing Project to be $1.14 \mathrm{Mb}$ and to encode 1041 putative proteins (Fraser et al., 1998). The T. pallidum genome sequence does not reveal any obvious classical virulence factors that could account for syphilis signs and symptoms (LaFond and Lukehart, 2006). Unlike the related spirochetes Treponema denticola (Girons et al., 2000) and B. burgdorferi (Eggers et al., 2002) no system for genetic manipulation of T. pallidum yet exists. Because of the fragility of its outer membrane, genetic manipulation of T. pallidum may prove impossible. Heterologous expression in related species such as $T$. denticola may be the most practical way to study $T$. pallidum genes and advance our understanding of this enigmatic organism (LaFond and Lukehart, 2006).

Spirochete $T$. pallidum subsp. pallidum belongs to a family of spiral-shaped bacteria, the Spirochaetaceae (spirochetes), and it is related to other pathogenic treponemes that cause non-veneral diseases. The T. pallidum subspecies are virtually identical based on their morphology, antigenic properties, and DNA homology, although more recent evidence suggests that there may be molecular signatures than can be used to differentiate the subspecies (Fenton et. al., 2008). T. pallidum lacks lipopolysaccharide (Fraser et al., 1998), the endotoxin found in the outer membranes of many gramnegative bacteria that cause fever and inflammation. However, T. pallidum does produce a number of lipoproteins which may induce expression of inflammatory mediators via toll-like receptor 2 (TLR2) recognition (Lien et al., 1999). The real antigens that contain the features of genetically uncongenial information and cause the production of antibodies in case of syphilis are T. pallidum subsp. pallidum itself or components of its parts. Basic antigens, the determinants of $T$. pallidum subsp. pallidum, are components of its triple layer outside wall, and in separate cases the capsule-shaped mucopolysaccharides coupler. Those most investigated are protein antigens of T. pallidum subsp. palli$d u m$, which contain a fraction known to be common in both pathogenic and saprophytic treponemas, and against which antibodies are raised. They contain also a fraction that is specific only to pathogenic treponemas. Components of $T$. pallidum subsp. pallidum proteins have high immunogenicity. Virulent T. pallidum subsp. pallidum induces cultured endothelial cells to express the adhesion molecules ICAM-1, VCAM-1, and E-selection. These are also activated by the 47-kDa T. pallidum lipoprotein TpN47 (Lee et al., 2000). Compared to the wealth of information about the disease-causing mechanisms of many bacterial pathogens, little is known about how T. pallidum causes the protean manifestations of syphilis. In the absence of cytotoxins and other known virulence factors, it is probable that inflammation and the ensuing adaptive immune response to T. pallidum subsp. pallidum cause the tissue destruction characteristic of syphilis infection. Specific T. pallidum subsp. pallidum molecules that have been shown to stimulate dendritic cells, the lipoproteins TpN17 and TnN47, are not surface localised. The initiation of lipoprotein signalling of dendritic cells is not likely to occur until the organisms are being depredated, exposing the lipoproteins to the TLR2 receptors. This theory is supported by observations that longer time than usual required for T. pallidum subsp. pallidum stimulation of dendritic cells (Bouis et al., 2001). A delay of dendritic cells maturation, resulting in slower inflammatory response, could allow the early dissemination of T. pallidum subsp. pallidum, giving organisms the opportunity to penetrate organs and tissues before an active inflammatory response has been mounted by the host.

Bacteriological investigation in the case of syphilis is not possible, because $T$. pallidum subsp. pallidum does not grow on artificial media. Two basic methods are applied in the routine diagnosis of syphilis-microscopy (excretions from an ulcer, erosion or punctuate obtained from a lymph node) using dark visual field and serology. Microscopy shows $T$. pallidum subsp. pallidum in all lesions of early and late syphilis, but not of latent syphilis. 
In the human organism antibodies against these proteins develop already at the end of the incubation period or during the first week after the onset of ulcus durum. The serological methods for diagnostics of syphilis are classified into non-specific (non-treponemal) and specific (treponemal) tests. In non-specific tests cardiolipin antigen obtained from bovine heart muscle is used. These are mostly flocculation tests, where the formed "antigen+antibody" complexes comprise flakes. In Latvia the non-specific tests, mostly SED (syphilis express diagnostics, microprecipitation reaction with lipid antigen), which is considered as a VDRL (Veneral Disease Research Laboratory)-modification and the RPR (Rapid Plasma Reagin) test are used. Nontreponemal tests are widely used for screening, although they are not reliable alone to confirm the diagnosis of syphilis. According to the European guidelines, non-treponemal tests are used for monitoring of serologic activity and treatment of syphilis (Goh and Voorst Vader, 2001).

Antibodies to specific antigens of Treponema pallidum subsp. pallidum in blood serum and/or plasma are detected using the specific tests. Commercially available test systems use Nichols' strain TpN15, TpN17 and TpN47 recombinant antigens and synthetic peptide TmpA. Other recombinant antigens Tp0453, Tp92, Gpd also can be used (Wesley et al., 2003), although such test systems are not commercially available. In Latvia now TPHA (Treponema pallidum hemagglutination test), ELISA (Enzyme-linked immunosorbent assay) and immunofluorescence test IFR (Fluorescent treponemal antibody-absorption test FTA-ABS) are applied. The abovementioned specific treponemal tests are used to confirm the diagnosis of syphilis and in differential diagnostics (Goh and Voorst Vader, 2001; Smith et al., 2001).

Historically, to confirm the cure of syphilis, in addition to non-treponemal tests, the reaction of complement binding (Wasserman) reaction and Treponema pallidum immobilisation reaction (TPIR) or Nelson test, both being specific tests, were used. Nowadays these tests are not used routinely, although the TPIR is applied in specialised laboratories in Latvia.

The diagnostic value of non-specific antibodies is limited: firstly, because in early primary disease antilipoidal antibodies may not have developed, and in late syphilis (late latent and tertiary) up to $30 \%$ of individuals may lack antilipoidal antibodies (Wesley et al., 2003); and secondly, because non-treponemal tests are highly sensitive in secondary syphilis, but in other forms their sensitivity is not sufficient (Table 1) (Larson, 1995). It is essential to find highly sensitive tests in monitoring serological activity and efficacy of treatment of latent syphilis.

Studies of this type have several problems, the major one being lack of a "gold standard" for the direct detection of T. pallidum subsp. pallidum. Serological confirmation may be delayed, absent, or difficult to interpret in cases of potential reinfection or reactivation of disease (Leslie et al., 2007).
Table 1

SENSITIVITIES OF SEROLOGICAL TESTS FOR SYPHILIS IN DIFFERENT STAGES OF DISEASE* (Larson, 1995)

\begin{tabular}{l|ccc|c}
\hline \multirow{2}{*}{ Test } & \multicolumn{4}{|c}{ Stage of syphilis } \\
\cline { 2 - 5 } & primary & secondary & latent & late \\
\hline VDRL (SED) & $78(74-87)$ & 100 & $95(88-100)$ & $71(37-94)$ \\
RPR & $86(77-100)$ & 100 & $98(95-100)$ & 73 \\
FTA-Abs & $84(70-100)$ & 100 & 100 & 96 \\
MHA-TP & $76(69-90)$ & 100 & $97(97-100)$ & 94
\end{tabular}

* Values are percent sensitivities. Numbers in parentheses represent ranges of sensitivities in studies at the Centre for Disease Control and Prevention.

VDRL - Venereal Disease Research Laboratory

SED - microprecipitation reaction with lipid antigen

RPR - rapid plasma reagin

FTA-ABS - fluorescent treponemal antibody absorption

MHA-TP - microhemaglutination assay for antibodies to T. pallidum

The goals of the investigation were:

1. To estimate and compare the sensitivity and specificity of SED, Syphilis Immunoblot IgG, and TPIR. A retrospective analysis of medical documentation was used as a reference.

2. To determine statistically correlation coefficients between values of TpN47 and TPIR, TpN17 and TPIR, TpN15 and TPIR, TmpA and TPIR, SED and TPIR results.

\section{MATERIALS AND METHODS}

Study population. Retrospective data of 52 treated late latent syphilis patients from the Clinical Centre of Skin and Sexually Transmitted Diseases Clinical Centre were analysed. These patients were hospitalised during a two-year period from December 2004 to December 2006. Treated late latent syphilis patients had received treatment at least three months before current assays were performed. The control group consisted of 21 patients without any association to syphilis.

Specimens. Syphilis Immunoblot IgG, SED and TPIR assays were performed on all specimens from patients. Serum specimens were analysed. Blood was collected by venous puncture and mostly centrifuged within two hours after blood collection. Blood was kept stoppered in the original container until ready for separation. The centrifugation was conducted for ten minutes at a relative centrifugal force of 850 to $1000 \times \mathrm{g}$ in the stoppered container. If analysis was to be delayed for more than four hours, serum was stored at $4^{\circ}-6^{\circ} \mathrm{C}$ until analysis. The duration of serum storage until running was seven days maximum.

Syphilis Immunoblot IgG. The commercially available test system INNO-LIA_Syphilis Score produced by INNOGENETICS (Gent, Belgium) was used (Ebel et al., 2000), which is a Line Immuno Assay, to confirm the presence of antibodies against $T$. pallidum subsp. pallidum. Three recombinant proteins (TpN47, TpN17, and TpN15) and one 
synthetic peptide (TmpA) are coated as discrete lines on a nylon strip with plastic backing. Specific T. pallidum subsp. pallidum antibodies, if present in the sample, will bind to the individual antigen lines on the strip. The assay was performed strictly following manufacturer's instructions.

SED. The commercially available cardiolipin antigen produced by "Biolik" (Kiev, Ukraine) was used (Smith et al., 2001). The assay was performed following the manufacturer's instructions.

TPIR. T. pallidum subspecies pallidum (Nichols' strain) was maintained and passaged by intratesticular inoculation of adult male rabbits in our laboratory. The infected rabbits were killed seven days after theinjection of Treponema suspension into testis. Treponema was extracted from the testes and harvested from testicular tissue debris by differential centrifugation. Spirochetes in suspension were counted by dark-field microscopy (Bouis et al., 2001). The negative control consists of the test serum and Treponema suspension, in a test tube containing $50 \mu \mathrm{l}$ serum, $300 \mu \mathrm{l}$ Treponema suspension and $150 \mu \mathrm{l}$ complement blood of guinea-pig obtained by intracardial punction. The incubation time of the test tube was 24 hours in $37{ }^{\circ} \mathrm{C}$. The test is judged negative compared with the control if up to $20 \%$ of spirochetes were immobilised, weak positive if $20 \%-50 \%$ of spirochetes were immobilised, and positive if more than $50 \%$ of spirochetes were immobilised.

Statistical calculations. Diagnostic sensitivity is defined as:

$\mathrm{SE}=\mathrm{TP} /(\mathrm{TP}+\mathrm{FN}) \times 100$, where

SE - diagnostic sensitivity, TP - number of true positive test results, FN - number of false negative test results.

Test specificity is the percentage of negative results in the non-infected patients:

$\mathrm{S}=\mathrm{AN} /(\mathrm{AN}+\mathrm{FP}) \times 100 \%$, where

$\mathrm{S}$ - test specificity, AN - number of actual negative test results, FP - number of false positive test results.

Results are identified as true positive and false negative results in relation to the retrospective study of the participants' clinical records.

Pearson's correlation coefficients were determined between test result parameters.

\section{RESULTS}

The sensitivity of the Syphilis Immunoblot IgG and TPIR was $98.1 \%$, sensitivity of SED was considerably lower, only $86.5 \%$.

The specificity of Syphilis Immunoblot IgG, TPIR and SED were $100 \%, 96.6 \%$, and $82.8 \%$, respectively.

A strong correlation (correlation coefficient $0.84, P<$ 0.001) was obtained between SED and TPIR results.
The medium strong correlation (correlation coefficient 0.61 , $P<0.001$ ) was observed between values of the synthetic peptide TmpA and SED, between values of TpN15 and TPIR (correlation coefficient $0.59, P<0.001$ ), and TpN47 and TPIR (correlation coefficient $0.54, P<0.001$ ). A poor correlation was found between values of TpN17 and TPIR (correlation coefficient $0.20, P<0.001$ ).

\section{DISCUSSION}

The sensitivity of non-treponemal tests for treated late syphilis patients is not sufficiently high, and therefore, the monitoring of treatment is not efficient. Our estimated sensitivity of SED $(85.5 \%)$ agrees with the data of VDRL (SED) $(71 \%,(37-94 \%))$ presented in Table 1 (Larson, 1995).

The obtained sensitivity and specificity of TPIR are high. TPIR assay is suitable to monitor syphilis serologic activity and treatment efficacy. The TPIR, considered as a "gold standard" but requiring a live culture of $T$. pallidum subsp. pallidum, is no longer routinely performed and has been replaced by more practical procedures. However, this method is technically complicated, expensive, and it is not possible to standardise.

Despite dramatic advances in other biomedical fields, the tools for the management and control of syphilis have undergone little change during the past 60 years (Edward et al., 2004). New molecular tests for syphilis are unlikely to replace serology in the short term because they are fairly expensive and require sophisticated equipment (Muller et al., 2006). Nevertheless, it is important to treat syphilis during pregnancy with penicillin and the endorsement of the use of molecular techniques to identify $T$. pallidum subsp. pallidum in clinical samples to diagnose congenital early syphilis is recognised (Woznicova et al., 2007). Also, a onestep sandwich chemiluminiscence immunoassay (CLIA) has been reported as a screening test and as a confirmatory test for the diagnosis of syphilis (Knight et al., 2007).

Due to the rapidly developing gene engineering in the last decades the functions and cell structure of $T$. pallidum subsp. pallidum have become better known. Tp15 lipoprotein has been determined recently, and antibodies against it are typically found in primary and congenital syphilis. Tp17 is considered to be a membrane protein. Maximum antibody development against it is found in patients with secondary syphilis. Antigens 42-44 (Tmp A) and $190 \mathrm{kD}$ polymer antigen are pathogenetically specific and are found also in other species of treponemas ( $T$. phagedenis). Antibodies against $190 \mathrm{kD}$ protein immobilise T. pallidum subsp. pallidum in the presence of inactivated serum. $47 \mathrm{kD}$ antigen is an immunologically dominant penicillin-binding protein that promotes cyclisation of antibodies both in the primary and secondary stage of syphilis.

Antibodies against separate recombinant proteins of T. pallidum subsp. pallidum (TpN17, TpN47, TpN15) can be de- 
termined in early stages of syphilis infection, during the period of incubation (in contact persons that receive preventive treatment) and in the case of primary syphilis. These aspects substantiate the necessity to use the test in the early stages of the disease.

The intensity of antibody production in later stages of syphilis (secondary, early masked) is maximal, and is expressed in immunoblot regarding all four recombinant antigens of $T$. pallidum subsp. pallidum.

High concentration of antibodies against T. pallidum subsp. pallidum antigens, particularly, TpN17 protein, is found in patients who have recently suffered from syphilis. In patients having syphilis in anamnesis (with duration of the disease for 3-5 years and more) this concentration is lower. Furthermore, the formation of antibodies against TpN17 protein is stable also during decreasing titres of antibody against TmpA protein.

The difference in levels of antibodies against different $T$. pallidum subsp. pallidum proteins during clinically serological testing can possibly be the substation in differential diagnostics in cases of serological resistance and increased negativity of blood serological reactions.

Nevertheless, there are differences in production of antibodies against different antigens of $T$. pallidum subsp. pallidum, and the end result of immunoblot testing in persons who had suffered from syphilis is always positive. A sample is considered positive if two or more syphilis bands show a reactivity of just \pm or higher (total number of bands is 4 , and the highest possible number of positive results is $+4)$. This proves the test to be presently non-replaceable, particularly in cases when the diagnosis of syphilis has to be determined retrospectively. The rate of assay specificity is high and it is a good confirmation test.

The use of recombinant $T$. pallidum subsp. pallidum antigens TpN47 (Tp0574), TpN17, TpN15 (Tp0171), TmpA, TpN44.5 (Tp0768), TpN17 (Tp0435) to demonstrate seroreactivity has advantages over lipoidal antigen-based and crude $T$. pallidum subsp. pallidum tests, which may have up to $30 \%$ false negative results in individuals with early and late syphilis (Wesley et al., 2003). Our study shows considerably higher sensitivity of Syphilis Immunoblot IgG in comparison with SED. This is in agreement with the results of the INNO-LIA ${ }^{\text {TM }}$ Syphilis obtained at the Institut Alfred Fournier (Ebel et al., 2000) and at OKCON (Hagedorn et al., 1999) where 681 of 683 syphilis-positive samples tested positive while two samples gave an indeterminate result$100 \%$ sensitivity including the indeterminate results. Thus, Syphilis Immunoblot IgG might be very effective for screening purposes in finding latent syphilis patients, but this test is presently rather expensive. According to our results, the estimation of values of TmpA, TpN15 and TpN47 might be useful in monitoring treatment efficacy of patients with latent syphilis.

\section{ACKNOWLEDGEMENT}

We thank Anders Kallner, MD, Associate Professor, Karolinska Hospital, Stockholm, Sweden for help and advice.

\section{REFERENCES}

Bouis, D.A., Popova, T.G., Takashima, A., Norgard, M.V. (2001). Dendritic cells phagocytose and are activated by Treponemma pallidum. Infect. Immun., 69(1), 518-528.

Brinkman, M.B., McKevitt, M., McLoughlin, M., Perez, C., Howell, J., Weinstock, G. M., Norris, S.J., Palzkill, T. (2006). Reactivity of antibodies from syphilis patients to a protein array representing the Treponema pallidum proteome. J. Clin. Microbiol., 44(3), 888-891.

Ebel, A., Vanneste, L., Cardinaels, M., Sablon, E., Samson, I., De Bosshere, K., Hulstaert, F., Zrein, M. (2000). Validation of the INNO-LIA_Syphilis as a confirmation assay for Treponema pallidum antibodies. Scand. J. Immunol., 38(215), 219-641.

Edward, W., Hook III, M.D., Peeling, R.W. (2004). Syphilis control—a continuing challenge. N. Eng. J. Med., 2, 351.

Eggers, C.H., Caimano, M.J., Clawson, M.L., Miller, W.G., Samuels, D.S. Radolf, J.D. (2002). Identification of loci critical for replication and compatibility of a Borrelia burgdorferi cp32 plasmid and use of a cp32-based shuttle vector for the expression of fluorescent reporters in the Lyme disease spirochete. Mol. Microbiol., 43, 281-295.

Fenton, K.A., Breban, R., Vardavas, R., Okano J.T., Martin, T., Aral, S., Blower, S. (2008). Infectious syphilis in high-income settings in the $21 \mathrm{st}$ century. Lancet Infect Dis., 8, 244-253.

Fraser, C. M., Norris, S. J., Weinstock, G. M., White, O., Sutton, G. G., Dodson, R., Gwinn, M., Hickey, E. K., Clayton, R., Ketchum, K. A., Sodergren, E., Hardham, J. M., McLeod, M. P., Salzberg, S., Peterson, J., Khalak, H., Richardson, D., Howell, J. K., Chidambaram, M., Utterback, T., McDonald, L., Artiach, P. Bowman, C., Cotton, M. D., Fujii, C., Garland, S., Hatch, B., Horst, K., Roberts, K., Sandusky, M., Weidman, J., Smith, H. O., Venter, J. C. (1998). Complete genome sequence of Treponema pallidum, the syphilis spirochete. Science, 281, 375-388.

Girons, I. S., Chi, B., Kuramitsu, H. (2000). Development of shuttle vectors for spirochetes. J. Mol. Microbiol. Biotechnol., 2, 443-445.

Gjestland, T. (1955). The Oslo study of untreated syphilis: An epidemiologic investigation of the natural course of the syphilitic infection based upon a re-study of the Boeck-Bruusgaard material. Acta Derm. Venereol., 35, 3-368.

Goh, B. T., Voorst Vader, P. C. (2001). European guideline for the management of syphilis. Int. Journal of STD\&AIDS, 12 (Supplement 3), 26.

Haake, D. V. (2000). Spirochetal lipoproteins and pathogenesis. Microbiology, 146, 1491-1504.

Hagedorn, J., Vanneste, L., De Bosshere, K., Pottel, H., Hulstaert, F., Van de Voorde, A., Zrein, M. (1999). Validation of the interpretation algorithm of INNO-LIA_ Syphilis using well-characterized sera. Innogenetics $N V$, Gent, Belgium, Study Report code DR-SYP-009, 1-11.

Knight, C. S., Crum, M. A., Hardy, R. W. (2007). Evaluation of the LIAISON Chemiluminescence immunoassay for diagnosis of syphilis. Clin.Vaccine Immunol., 14(6), 710-713.

LaFond, R. E., Lukehart, S. A. (2006). Biological basis for syphilis. Clin Microbiol Rev, 19(1), 29-49.

Larson, S. A. (1995). Laboratory diagnosis and interpretation of tests for syphilis. Clin. Microbiol. Rev., 8, 1 .

Lee, K. H., Choi, H. J., Lee, M. G., Lee, J. B. (2000). Virulent Treponema pallidum $47 \mathrm{kDa}$ antigen regulates the expression of cell adhesion molecules and binding of T-lymphocytes to cultured human dermal microvascular endothelial cells. Yonsei Med. J., 41, 623-633.

Leslie, D. E., Azzato, F., Karapanagiotidis, T., Leydon, J., Fyfe, J. (2007). Development of a Real-Time PCR Assay to detect Treponema pallidum in 
clinical specimens and assessment of assay's performance by comparison with serological testing. J. Clin. Microbiol., 45(1), 93-96.

Lien, E., Sellati, T. J., Yoshimura, A., Flo, T. H., Rawadi, G., Finberg, R. W., Carroll, J. D., Espevik, T., Ingalls, R. R., Radolf, J. D., Golenbock, D. T. (1999) Toll-like receptor 2 functions as a pattern recognition receptor for diverse bacterial products. J. Biol. Chem. 274, 33419-33425.

Muller, I., Brade, V., Hagedorn, H., Straube, E., Schorner, C., Frosch, M., Hlobil, H., Stanek, G., Hunfeld, K. (2006) Is serological testing a reliable tool in laboratory diagnosis of syphilis? Meta-analysis of eight external quality control surveys performed by the German Infection Serology Proficiency Testing Program. J. Clin. Microbiol., 44(4), 1335-1341.

Ozoliņ̌̌, D., Hartmane, I., Dērveniece, A., Pakalne, V., Žileviča, A. (2006). Diagnostics of syphilis: Evaluation of the enzyme-linked immunosorbent assay of IgG and IgM in comparison with other methods of serological diagnostics. Proc. Latvian Acad. Sci., Section B, 60(4), 127-132.

Porcella, S. F., Schwan, T. G. (2001). Borrelia burgdorferi and Treponema pallidum: A comparison of functional genomics, environmental adoptions and pathogenic mechanisms. J. Clin. Invest., 107(6), 651-656.

Rompalo, A. M., Joesoef, M. R. , O’Donnell, J. A., Augenbraun, M., Brady, W., Radolf, J. D., Johnson, R., Rolfs, R. T. (2001). Clinical manifestations of early syphilis by HIV status and gender: results of the syphilis and HIV study. Sex. Transm. Dis. 28, 158-165.
Smith, M. B., Hayden, R. T., Persing, D. H., Woods, G. L. (2001). Spirochete infections. In Clinical diagnosis and management by laboratory methods (pp. 1131-1144). Philadelphia; London; New York; St. Louis; Sydeny; Toronto: Henry J. B. Sounders Company.

Walker, E. M., Arnett, J. K., Heath, J. D., Norris, S. J. (1991). Treponema pallidum subsp. pallidum has a single, circular chromosome with a size of approximately 900 kilobase pairs. Infect. Immun. 59, 2476-2479.

Walker, E. M., Howell, J. K. , You, Y., Hoffmaster, A. R., Heath, J. D. , Weinstock, G. M., Norris, S. J. (1995). Physical map of the genome of Treponema pallidum subsp. pallidum (Nichols). J. Bacteriol., 177, 1797-1804.

Wesley, C. V., Barrett, L. K., Lukehart, S. A., Schmidt, B., Schriefer, M., Cameron, C. E. (2003). Serodiagnosis of syphilis: Antibodies to recombinant Tp0453, Tp92 and Gpd proteins are sensitive and specific indicators of infection by Treponema pallidum. J. Clin. Microbiol., 41(8), 3668-3674.

Woznicova, V., Smajs, D., Wechsler, D., Matejkova, P., Flasarova, M. (2007). Detection of Treponema pallidum subsp. pallidum from skin lesions, serum, and cerebrospinal fluid in an infant with congenital syphilis after clindamycin treatment of the mother during pregnancy. J. Clin. Microbiol., 45(2), 659-661.

Woznicova, V., Valisova, Z. (2007). Performance of CAPTIA SelectSyph-G Enzyme-Linked Immunosorbent Assay in syphilis testing of a high-risk population: Analysis of discordant results. J. Clin. Microbiol., 45(6), 1794-1797.

Received 8 August 2008

\section{OPTIMIZĒTAS IKDIENAS PRAKSĒ LIETOJAMAS LATENTA SIFILISA DIAGNOSTIKAS UN SLIMĪBAS GAITAS NOVĒROŠANAS METODES}

Vērtējot latenta sifilisa slimības gaitu un seroloǵisko aktivitāti, svarīgi ir izmantot testus ar augstu jutību un specifiskumu. Retrospektīva pētījuma ietvaros Ādas un seksuāli transmisīvo slimību klīniskajā centrā tika analizēti 52 latenta sifilisa pacienti, kuriem bija ordinēta ārstēšana pret sifilisu. Tika aprēķināta sifilisa imunoblota IgG, bālās treponēmas imbilizācijas reakcijas (BTIR) un sifilisa ekspresdiagnostikas testa (SED) jutība un specifitāte. Tika izrēkināta korelācija starp bālās treponēmas imobilizācijas reakcijas (BTIR) un sifilisa imunoblota IgG, SED un bālās treponēmas imobilizācijas reakcijas (BTIR) rezultātiem. Sifilisa imunoblotu IgG ir lietderīgi izmantot latenta sifilisa diagnostikā. Sintētisko peptīdu TmpA, TmpN15 un TmpN47 vērtības uz sifilisa imunoblota IgG stripa ir lietderīgi izmantot latenta sifilisa pacientu ārstēšanas monitorēšanā. 